\title{
Blindness: the Novel and the Film. From Sophocles to Saramago and Meirelles
}

\author{
Luís Miguel Cardoso
}

\begin{abstract}
The symbolic value of blindness that goes beyond physical evidence and transports the reader to universal dimension of the great existential options and the most basic needs of Man is a thematic and ideological structuring vector in the novel Blindness by José Saramago. From Literature to Cinema, this reading gains universal dimension that rises from the novel and becomes an attempt to visualize the word, building a visual metaphor. However, the theme of blindness as an interpretation of Man is still relevant, as Sophocles did in his King Oedipus. This is the symbolic path that is born in Sophocles and crosses Saramago until reaching Meirelles.
\end{abstract}

Keywords - Portuguese Literature, Film Adaptation, Adaptation Theory, Blindness.

\section{INTRODUCTION}

Since the birth of cinema as an art, literature has given the so-called seventh art numerous narratives, drama or poems that served as the basis for filmmaking. With this connection between literature and cinema, a problematic concept arises that is still discussed today: adaptation. Portuguese cinema also found an inexhaustible source of films in literature, often inspired by highly regarded books and known to the public.

As Akmese (2019) wrote:

This strong relationship between literature and cinema stems from their ability to explain the topics they deal with in detail. Since both fields of art are nourished by similar dynamics, many works have been adapted from literature to cinema. The first adaptation from literature to cinema in history is Melies's movie A Trip to the Moon (1902), which was inspired by Jules Verne and H. G. Wells's books; this film is followed by many more adaptations, the film A Trip to the Moon has an important place in the history of cinema as it is both the first adaptation and the first example of the science fiction genre. Today, the technique of adapting from literature to cinema is among the methods used by many directors. (2019, p. 1)

Luís Miguel Cardoso, Polytechnic Institute of Portalegre and Centre for Comparative Studies of the University of Lisbon (Portugal)
Recently, the most famous examples of adaptations of Portuguese literature to the cinema include novels by highly respected authors: Blindness (2003), Mysteries of Lisbon (2010), Os Maias (2014), O Homem Duplicado (2014), Pilgrimage (2017), Aparição (2018), or the Year of the Death of Ricardo Reis (2020).

However, in the genesis of all adaptations, there is a process of metamorphosis from literature to cinema: the phenomenon of adaptation.

Even today, we can find a strong presence of literature at the box office, because literature continues to be a profound source for new films, and arouses discussions among film and literature critics as Perdikaki (2018) writes:

Film adaptation has been considered as a genre in its own right and, according to some scholars, as the defining genre of American film production (cf. Cartmell 2010; Leitch 2008). The process of transposing a literary work onto the big screen is often discussed in translational terms and research in Adaptation Studies has touched upon the similarities between translation and adaptation as creative processes and as cultural phenomena. More specifically, Cattrysse (2014: 47-49) builds on the 1970s system of theories in order to highlight the common characteristics between translation and adaptation as processes and products. He observes that both involve the interaction of users with texts in a socio-temporally defined context and argues that both are teleological processes, in that they are influenced by source and target (con)text conditioners, the latter of which play a pivotal role in the overall decision-making. (2018, p. 169)

On the literary origin of the adaptations, Akmese (2019) wrote:

Literature is the area of art most intertwined with the cinema. How the literary work to be adapted to the film is reconfigured and whether this literary work serves as the basis of direct adaptation or inspiration are matters of particular importance in view of the nature of the relationship established between the novel and the film (Boz, 2014, p. 113). (2019, p. 5)

The issue of relations between the original and the film is highlighted by Perdikaki (2018):

Adaptations affirm their value as creative entities through reinterpreting the source material and assigning new messages to it. Such reinterpretation is inextricably linked with the adapters' creative vision and individual 
intertexts. Adaptation is a context-dependent process which draws its meaning from the readings (and/or viewings) afforded in the given socio-temporal and cultural context. Casetti (2004) posits literature and film as sites where discourses are produced and circulated, and thus signify meanings considered as possible (thinkable) and feasible (legitimate) by the given sociocultural community. Therefore, adaptations do not deal merely with texts but with the complex meanings conveyed by texts in different contexts and to different target audiences. This in turn creates a dialogue between text and context and also enriches the identity of the source text, which harks back to the hermeneutic motion present in adaptation. (2018, p. 173)

In the most recent years, one of the novels that most aroused interest in the universe of adaptations was the novel Ensaio sobre a Cegueira, by the Portuguese José Saramago, Nobel Prize for Literature. About the adaptation process, the Brazilian director Fernando Meirelles wrote a book entitled "Diário de Blindness", in which he writes about the dialogues he maintained with Saramago about the construction of the film.

One of the questions that we immediately think of is the relationship with the Greek tragedy King Oedipus, by Sophocles, in which Oedipus is blinded, after learning that he had killed his own father. The value of this blindness has always aroused countless interpretations. As Grelka wrote:

Oedipus relies on the knowledge acquired by means of visual perception and this knowledge provides him the illusion of control over the situation, but at the same time he actually has no reliable information about his own life. It is even more paradoxical in the face of the fact that he accuses other people of ignorance. The allegation can be brought because the one who brings it possesses all the sensory faculties (especially the visual ones) - Oedipus is deeply convinced of the superiority of the knowledge acquired by means of visual perception. (...) In the culminating point of the tragedy (1369 and sqq.) Oedipus acquired the true knowledge, but at the cost of losing the ability to see. This could be interpreted twofold, taking acquisition of knowledge or physical blinding as a starting point for the interpretation. On one hand Oedipus gained true divine knowledge having been isolated from the visual side the external reality (similarly to Teiresias) and became disinterested in human knowledge once he had the true one. What is more, while it is true that the very tragedy of Oedipus is in some ways distinctive and very unique,30 it is Oedipus himself, being "no more than, and no less than, a man", as R. Buxton writes, that could be an incarnation of human blindness in general. (2013, p. 2023)

They talked about Danny Glover playing the Old Man of Venda Preta, who acts as a writer's alter ego, just as the director thinks the character. Glover, like Saramago, is a man with enormous vitality. The character she plays has a black blindfold in one eye and a cataract in the other, which connects to the writer, due to the heavy glasses he wears. According to Meirelles, because he doesn't see very well, the character lives more in contact with his inner world and not with the world around him, which, after all, is superficial and sensory, and even with the white blindness that attacks the population, he can see and better understand everything that goes on. For this reason, Saramago wrote in the title of the book "IF you can look, see. If you can see it, take a look". The writer intends to warn of the need to see with an analytical perspective and not just with a mechanical view. It is necessary that man move away from superficiality and truly understand the interior of Man, his life and subjectivity. For Meirelles, Glover's performance will be like including the writer himself in the film.

Meirelles found Saramago who always refused to sell the rights of the novel to the cinema, because he believed that the cinema destroyed the imagination. However, he was very enthusiastic about the Brazilian director's project and made himself available to collaborate in the entire process.

Meirellles knows that adaptation will be a difficult process and writes:

Essay on Blindness allows so many readings that at all times I check whether this or that detail of the story is included in what I have filmed. This is a text that generates many questions, but no answer, raises questions about the evolution of man, which makes us reflect critically, but does not point out directions. Each one will have to find the way through himself. I believe that, because it is so open, the book allows everyone to read it by projecting their own questions and all the readings seem to make sense. It is not for nothing that so many people say that this is their favorite book, That, I had done a film with $5 \%$ of that quality. The first image that came to me when I read the Essay on Blindness was that of our civilization as a complex structure, like those formed at random in a Mikado game. A chopstick is removed suddenly (the view) and the whole structure collapses. I was interested in this story because it exposes the fragility of this civilization that we consider so solid. In our society, the limits of what we think is civilized are broken daily, but it seems that we do not realize it, barbarism is installed and we do not see or do not want to see. For me, that was what the book was about. The white blindness metaphor illustrates our lack of vision. "I don't think we were blind," says one character. "I think we are blind. Blind who can see, but cannot see ". How much suffering do we have to go through so that we can open our eyes and see? That was the promising question I asked myself when closing the last page of the book. (2008, 31-32)

For the director, the book is about the collapse of the individual and not so much about the collapse of civilization.

When they lose their sight, perosonages lose the entire path of civilization that has been done for thousands of years and come to be dominated by the most basic instincts: to eat, to 
breed, like any animal in the wild. Only the recovery of family structure and affection will allow a return to the lost condition. In this sense, this is the story of a woman who rises in barbarism to maintain human dignity. The writer himself valued this idea:

"... In the case of the Essay on Blindness, that is still my hope: that women can take a new place in the world and invent a new way of being." There are those who make a more political reading; read here a story about the creation of a society in which the only possible way out depends on the abandonment of individual aspirations in favor of the collective good (...) It is also a book about the ghosts that our mind creates to torment and arrest us ( ...) What will be the best leader, the Doctor, who leaves the inhabitants of Camarata 1 to go hungry for always trying to act ethically, or the King of Camarata 3, who simply takes all the food and then charges for it on behalf of the their? Is it lawful to invade a third-party dormitory / country for the sake of your people? (...) What does honor and dignity mean? (2008, pp. 33-34)

There are differences between the book and the film. For example, in the script, a discussion arises between the First Blind Man and The Woman of the First Blind Man, which are presented, already in full discussion. The Woman is deeply selfish and cannot support her husband, even when she loses her sight, contrary to what happens in the novel.

We also noticed that Meirelles created several narrators. The Old Man from Venda Preta replaces the Doctor's Woman at some point. Before, we had the camera that we knew as much as the doctor's wife, but now we have a new narrator who tells everything that goes on inside the characters, tells a very deep story and adds another layer to the film. In the end, we have the story that is narrated by the director, by the Doctor's Wife, respectively his voice and her eyes, as well as by the camera. Meirelles explains the evolution of the three acts:

This change of narrator affects the language and sets the pace for the film. The first act of the film is more classic, the story advances nimbly the way it happens in most films. In the second act, the observation of the Doctor's Woman, the film travels more, is less objective and wanders like a woman (yes, women are better at ramblings than men). Finally, when the narration of Velho Da Venda Preta enters, the film returns to a more linear intrigue, but added to a reading of what is happening. These three ways of telling the story give the film its face and that was already indicated in the script. In other words, any decision by the screenwriter can radically transform the film not only in its content, but in its format. (...) With this film, I learned that sometimes it is not necessary to move the intrigue, the simple displacement of the point of view, the change of narrator, generates enormous movement even if the action stops. (2008, p. 50)

In May 2008, Meirelles showed the film to Saramago. The
Portuguese writer told the Brazilian director that he felt as happy on the day of the film's viewing as on the day he finished writing his novel. He said that he did not consider the film a mirror of his work and it could not be that way because each person has his sensitivity. He said that the film was not perfect, but that he had also never seen a perfect film.

In fact, Saramago spoke of an eternal question: the relationship between the novel and the film. This relationship should not be evaluated according to Seconds of fidelity or dependence of the film in relation to the book. We need to address the issue of the transformations that occur in the adaptation process, which raises numerous questions and very diverse theories.

All of these evaluation criteria do not show the main operating principle in the analysis of adaptations: the phenomenon that Bluestone calls "mutation process". According to this author, most critical judgments are not illuminated by what can be defined as "transcoding procedures" (Reis \& Lopes, 1997), that is, an analysis of the transformations inherent to the process of mutation from a semiotic system to other. As Perdikaki wrote, like Syniard, Zumalde, Seger, Noriega or Catrysse:

Adaptatins affirm their value as creative entities through einterpreting the source material and assigning new messages to it. Such reinterpretation is inextricably linked with the adapters' creative vision and individual intertexts. Adaptation is a context-dependent process which draws its meaning from the readings (and/or viewings) afforded in the given socio-temporal and cultural context. (2018, p. 173)

\section{REFERENCES}

[1] Akmese, Z. (2019). Adaptation of the novel The Stranger: a comparative framing analysis of the films Lo Straniero and Yazgı. Connectist: Istanbul University Journal of Communication Sciences, 57, 1-23. https://doi.org/10.26650/CONNECTIST2019-0064

[2] Meirelles, F. (2008) Diário de Blindness. Vila Nova de Famalicão: Quasi Edições

[3] Bluestone, G. (1957) Novels into Film. Berkeley: University of California Press

[4] Cattrysse, Patrick. (2018). The Study of Historical Films as Adaptation: Some Critical Reflections: Scripting Real Lives. 10.1007/978-3-31997322-7_2.

[5] Grelka, M. (2013). On the question of knowledge and blindness in Sophocles' Oedipus tyrannus. SYMBOLAE PHILOLOGORUM POSNANIENSIUM GRAECAE ET LATINAE XXIII/1. pp. 19-33. ISBN 978-83-7654-209-6. ISSN 0302-7384

[6] Noriega, J. (2000) De la literatura al cine. Paidós: Barcelona

[7] Perdikaki, K. (2018). Film adaptation as the interface between creative translation and cultural transformation: The case of Baz Luhrmann's The Great Gatsby. The Journal of Specialised Translation. Issue 29 January 2018. Pp. 169 - 175

[8] Reis, C. \& Lopes, A. (1997) Dicionário de Narratologia. Coimbra: Almedina

[9] Seger, L. (2000) El arte de la adaptación. Madrid: RIALP

[10] Syniard, N. (1986) Filming Literature. The Art of Screen Adaptation. London: Croom Helm

[11] Zumalde, I. (1997) Deslizamientos Progresivos del Sentido. Traducción/Adaptation, Valência: Ediciones Episteme 


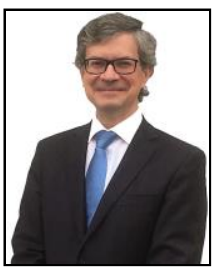

L. Cardoso was born in Viseu (Portugal) in 1969. After concluding the Humanities degree at the Catholic University in 1991, he concluded a Master in Classic Literatures at Coimbra University, in 1996. In 2007 he concluded his PhD in Modern Languages and Literatures at Coimbra University (Portugal). After teaching for four years in secondary schools, he began teaching at the Polytechnic Institute of Viseu in 1995 until 2008, when he moved to the Polytechnic Institute of Portalegre as Adjunct Professor. He was elected Dean of the School of Education and Social Sciences in 2010 until february 2018, completing the two mandates permitted by law. Since 2015 until May, 2018, he was also President of ARIPESE - the Association for Reflexion and Intervention in Higher Schools Polytics. Main interests in teaching and investigation include Science and Communication Languages, Literature and Cinema, and Management of Higher Education Universities. In 2016, he published Literature and Cinema: the look of Janus. Vergílio Ferreira and the space of the unspeakable. Prof. Dr. Cardoso was the national coordinator for the Bologna Process in Polytechnics in Media and Communication Sciences. He is a member of several international organizations concerning Education, Communication, Comparative Literature, Narratology, Film Studies and Higher Education Management and reviewer of several international journals. He has published several papers in national and international journals with peer review and is a member of $\mathrm{C} 3 \mathrm{i}$ - Polytechnic Institute of Portalegre and of the Center for Comparative Studies of the University of Lisbon. 